\title{
An Investigation into the Hybridity Phenomenon of Poetry Translation in Hong Lou Meng
}

\author{
Ying Li \\ Foreign Language School \\ Huanghe Science and Technology College \\ Zhengzhou, China
}

\begin{abstract}
Hong Lou Meng is regarded as one of the "Four Great Classical Chinese Novels", in which the peotry (namely, poems, lyrics, tunes, $\mathrm{Fu}$ and so on) are always glittering in the Chinese literary treasure land. Many scholars in China and the West are devoted in the research and translation of Hong Lou Meng, and there have been many translated versions of Hong Lou Meng, among which the two most famous full-text versions are translated respectively by the Yangs and David Hawks. Scholars commonly regard that the Yangs' version adopted the foreignization strategy and David Hawkes' version adopted the domestication strategy. However, the author of the present paper holds that there are actually no abusolute foreignization and domestication, and that all the versions are hybridized translation. Thus the hybridity theory is introduced into the research of the poetry translation in Hong Lou Meng. The paper aims to study the hybridity phenomenon in the poetry translation in Hong Lou Meng by comparing its two full-text translated versions (the Yangs' version and Hawkes' version). Hybridity, different from domestication and foreignization, offers a third space for the research of poetry translation in Hong Lou Meng.
\end{abstract}

Keywords-domestication; foreignization; hybridity; degree of hybridit; poetry in Hong Lou Meng

\section{The STUdies OF Hong Lou Meng AND ITS TRANSLATIONS}

Cao Xueqin's Hong Lou Meng is a world famous masterpiece which is regarded as one of the "Four Great Classical Chinese Novels". It is universally acknowledged as the summit of classical Chinese novels. Revolving around the tragic love between the two protagonists- Jia Baoyu and Lin Daiyu, this novel provides a detailed description of various contradictions in four great aristocratic families (namely, Jia, Shi, Wang and Xue), and demonstrates before readers a vivid landscape of the Chinese feudal culture, such as clothing, food, architecture, social system, social customs, conventions, education, literature, art and philosophy. What deserves to be mentioned is that there are more than two hundred wonderful traditional Chinese poems in this great novel. These poems seem to be composed freely by the characters; however, they are all well designed by the author Cao Xueqin and serve as an indispensible part of the whole.

Hong Lou Meng has been translated into many languages in the worldwide, but most of them are selected translations.
This paper mainly focuses on two full-text translated English versions: one is The Story of the Stone translated by David Hawkes and John Minford, the other is A Dream of Red Mansions translated by Yang Xianyi and Gladys Yang. Since the poems play a very important part in this novel, research on the translation of these poems seems to be of great importance.

\section{THE HYBRIDITY THEORY AND THE HYBRID PHENEMENA IN HONG LOU MENG}

The term "hybridity" was from Homi Bhabha's famous work entitled The Location of Culture [1], in which he had made a detailed analysis about the theory of hybridity in translation. It aims to deconstruct and demystify the classical canon of the Western imperial colonialism, to resist the Euro-American cultural hegemony, to diminish the West centrism, to eliminate the binary opposition, and to reconstruct the subjectivity of the Subaltern and the "minorities" or the weak culture with the aspiration to help them find their own cultural identity. Hybridity, different from domestication and foreignization, offers a third space for translation studies.

As far as translation strategy is concerned, it is universally acknowledged that the Yangs adopt the foreignization-oriented translation strategy, while Hawkes and John Minford adopt domestication-oriented translation strategy. However, this commonsense often leads people to form a false concept that Yang's strategy is pure foreignization, while Hawkes's strategy is pure domestication. In fact, no translation is done by adopting the only foreignization or only domestication, and all translations are the result of the combination of the two. The difference is in the degrees of hybridity in different translations.

\section{ANALYSES OF HYBRIDITY PHENOMENON IN Translating PoEMS IN Hong Lou MENG}

Case (1)

In chapter sixty-four, in order to express her sadness and pity for the miserable endings of five beauties in ancient times, Lin Daiyu writes down five poems. Here is one of them: 
五美吟・虞姬

断肠乌雅夜啸风，虞兮幽恨对重瞳。

黝彭甘受他年酾, 饮剑何如楚帐中。

a. Version by the Yangs:

Lady $\mathrm{Yu}$

Heart-broken as black steed neighing at night in the wind,

In silent grief she stayed beside her lord;

The renegades Qing $\mathrm{Bu}$ and Peng Yue were doomed to be slaughtered;

Better, then, in Chu's tent to fall on her own sword[3].

b. Version by Hawkes and Minford:

Yu Ji air.

The very crows are grieving as they caw in the cold night despair:

She faces her beaten Tyrant King with a haggard look of

Let the others wait for the hangman, to be hacked and quartered and rent;

Better the taste of one's own steel in the decent dark of a tent [4].

In this poem, Lin Daiyu mentioned four persons (“虞” refers to $\mathrm{Yu} \mathrm{Ji}$, “重瞳”refers to Xiang Yu, “黥彭”refer to Qing $\mathrm{Bu}$ and Peng Yue), by comparing their different endings, she speaks highly to Yu Ji's love and loyal to Xiang $\mathrm{Yu}$. Actually, some people consider that it is Cao Xueqin, the author of Hong Lou Meng who wants to imply his suffering by mentioning the historical characters and events. The story is about the battle between Liu Bang and Xiang Yu in Gaixia. Later, Xiang $\mathrm{Yu}$ is defeated, and commits suicide after $\mathrm{Yu}$ Ji's suicide. Qing Bu and Peng Yue, who were subordinates of Xiang Yu, later betrayed him and were finally slaughtered by Liu Bang.

The Yangs attempt to maintain the heterogeneous elements of the source text in the target text. By using "heartbroken black steed", "In silent grief", "Qing Bu and Peng Yue", "Chu's tent", "fall on her own sword", and etc., the Yangs' version successfully transmit the otherness of the original text into the English language and culture. On the contrary, in Hawkes's version, some cultural points are misunderstood or even omitted, for instance “乌雅” is translated as “crow”, “重瞳” is omitted, “黥彭” is simply replaced by “the others", and “饮剑” and “楚帐” are respectively translated as "the taste of one's own steel" and "the decent dark of a tent", all of which are not adequate translation. Anyway, there are also some defects in the Yangs' translation, but in terms of hybridity, the degree of hybridity in the Yangs' version is much higher than that in Hawkes's.
From the example mentioned above, it can be easily found that words with culture specialty, if translated under the guidance of hybridity strategy, could bring new elements, making English no more as pure as what the western readers used to see, and defying the authority of English language and culture. This will help to rewrite the superior culture and hybridize it with the inferior culture so as to weaken and dethrone the authority of the former and enable the inferior culture to get its legitimate identity. Meanwhile, this kind of translation helps to enhance readers' sense of cultural difference and promote the equal communication between different cultures[5].

Case (2)

The twelve overtures in Hong Lou Meng foretell the endings of twelve beauties. These overtures entail rich cultural elements which add immense difficulty to translaton. The following one named "Wang Ning Mei" reflects the religious culture.

\section{枉凝眉}

一个是阆苑仙苑, 一个是美玉无瑕。若说没奇缘, 今生偏又遇着他, 若说有奇缘, 如何心事终虚化? (曹雪芹: 第五回)

a. Version by the Yangs:

Vain Longing

One is an immortal flower of fairyland,

The other fair flawless jade,

And were it not predestined

Why should they meet again in this existence?

Yet, if predestined,

Why does their love come to nothing?

b. Version by Hawkes and Minford:

Hope Betrayed

One was a flower from paradise,

One a pure jade without spot or stain.

If each for the other one was not intended,

Then why in this life did they meet again?

And yet if fate had meant them for each other,

Why was their earthly meeting all in vain?

This poem is mainly about the love between Jia Baoyu and Lin Daiyu. The two versions both choose to translate in the form of poems, and readers can feel the strong rhythms of poems. However, there exist some different features in their versions. In this poem, there are some religious cultureloaded words or phrases, like “阆苑仙菂”, “奇缘” and “今 
生”, but the translation of these culture-loaded words shows the translators' different religious cultural inclinations in their translations.

The Yangs' version is filled with features of Chinese culture. For instance, the title of “枉凝眉” is translated into “vain longing”, “阆苑仙菂” into “immortal flower of fairyland" in which “阆苑” is a term for Taoism, “有奇缘” into "be predestined”, “今生” into “this existence” (“奇缘” “今生” are terms from Buddhism).All these translations are carried out with respect to the source text and source culture, and precisely express the intension of the author. But the Yangs' version is not easily accepted by the western readers. In order to cater for western readers' reading taste, Hawkes's translation has made several changes. For example, he renders “枉凝眉” into “hope betrayed”, “阆苑仙范” into “flower from paradise", “有奇缘” into "be intended”, “今 生” into "this life". It is evidently that these words are lightened in his translation.

Comparing the two, the Yangs' version attempts to regain the otherness in the original text. Therefore, the Yangs' version enjoys much higher degree of hybridity than that of Hawkes'. However, we can not simply deny Hawkes's translation by this; anyhow, Hawkes has made great contribution in introducing Chinese culture to western readers.

\section{Case (3)}

The following poem is from the thirty fourth chapter of Hong Lou Meng. Baoyu is severely beaten by his father, and finds that Lin Daiyu is visiting him when wake up. After Lin Daiyu leaves, Baoyu asks his maid Qingwen to send two old handkerchiefs to Lin Daiyu so as to comfort her not to worry about him too much and express his love to Daiyu. And Lin is so deeply moved that she could not help writing three four-line poems on the handkerchief. The following lines are the selection from these four line poems.

\section{彩线难收面上珠, 湘江旧迹己模糊; \\ 窗前亦有千竿竹，不识香痕渍也无?}

a. Version by the Yangs:

No silk thread can string these pearls:

Dim now the tear-stains of those bygone years:

A thousand bamboos grow before my window--

Is each dappled and stained with tears[3]?

b. Version by Hawkes and Minford:

Yet silk preserves but ill the Naiad's tears;

Each salty trace of them fast disappears.

Only the speckled bamboo stems that grow

Outside the window still her tear-marks show[4]

It can be seen that all these lines concentrate on one word 一“tears”. “湘江旧迹”, “千竿竹” and “香痕渍” refer to the allusion in which " the two imperial concubines Ehuang and
Nvying's tears leave spots on the bamboo after the emperor Shun's death." This allusion carries the legend of mottled bamboo (“千竿竹”). Apparently, Lin Daiyu compares herself to Ehuang and Nvying in order to express her affection for Jia Baoyu by putting these allusions into the poem. How to render the implied meaning of this poem is the key to successful translations.

By comparing the two versions, it can be found that neither of them conveys the connotation of the poem adequately, and the poem is simplified by omitting the legend. In the Yangs' version, “湘江旧迹” and “千竿竹” are literally rendered into "the tear-stains of those bygone years" and "a thousand bamboos" and in Hawkes's version, “湘江 旧迹” and“千竿竹” are respectively translated into “salty trace" and "the speckled bamboo stems". In short, both the two versions are not adequate in terms of translation hybridity and one possible suggestion is to give some notes in the translation to compensate the loss of implication.

Case (4)

蛾眉颦笑兮,将言而未语, 莲步乍移兮,待止而欲行. 羡 彼之良质兮, 冰清玉润, 羡彼之华服兮, 闪灼文章. 爱彼之 貌容兮,香培玉环, 比美人之态度兮,凤翥龙翔.......

\section{(曹雪芹：第五回)}

a. Version by the Yangs:

... Her mothlike eyebrows are knit yet there lurks a smile, and no sound issues from her lips parted as if to speak as she glides swiftly on lotus feet and, pausing, seems poised for flight. Her flawless complexion is pure as ice, smooth as jade. Magnificent her costume with splendid designs. Sweet her face, compact of fragrance, carved in jade; and she bears herself like a phoenix or dragon in flight. ....[3]

\section{b. Version by Hawkes and Minford:}

A half-incipient look of pique

Says she would speak, yet would not speak;

While her feet, with the same irresolution,

Would halt, yet would not interrupt their motion.

I contemplate her rate complexion,

Ice-pure and lade-like in perfection;

I marvel at her glittering dress,

Where art lends grace to sumptuousness;

I wonder at her fine-cut featured-

Marble, which fragrance marks as one with living creatures;

And I admire her queenly gait,

Like stately dance of simurgh with his mate.[4]

This piece is a vivid description about the Goddess of Disenchantment, which can be viewed as a typical traditional Chinese beauty. As far as translation strategy is concerned, 
we can not neglect the two important strategies, i.e., foreignization and domestication put forward by Laurence Venuti. However, the roots of domestication and foreignization can be traced back to Schleiermacher's assertion in his essay, in which Schleiermacher offers two methods to do translation: either the translator leaves the author in peace, as much as possible, and moves the reader towards him; or he leaves the reader in peace, as much as possible, and moves the author towards him[6] .

The language form in source text is called “Fu" (赋), a special language form which seems both like the poem and the prose. The Yangs attempt to translate it with the form of prose so as to keep the rhythms and charm of the source text, especially for the Chinese cultural images such as “蛾眉”,

“莲步”, “龙”, “凤”, etc., the Yangs keep the original images with "mothlike eyebrows", "lotus feet", "dragon" and "phonenix", while Hawkes generalizes or changes the Chinese cultural images. In Hawkes's version, readers can not find the images of “蛾眉”, “莲步”, and “龙”, “凤”, they are replaced by "simurgh" and its mate. Therefore, whether in the form or the content, the degree of Hybridity in the Yangs' version is much higher than Hawkes's version.

But generally speaking, Yang's version is more faithful to the original version than Hawkes's version. Yang's version is trying to be close to the source text, both in form and content, while Hawkes's version changes too much, just like English rewriting. In Hawkes's translation, this poem seems not to be from a Chinese classical novel, but from a popular piece. Yang's version tries very possible means to keep the heterogeneous elements of the original text, and of course have very high degree of hybridity.

Through the above analysis, we can have a relatively objective comparison between the Yangs' version and Hawkes's version. If we re-translate the Yangs' version and Hawkes's version back into Chinese, we will find that the back-translation of former is, in general, much closer to the original red-poems. In this way, we can find that the Yangs' version has higher degree of hybridity than Hawkes's version.

\section{CONCLUSION}

Classical Chinese poetry is a precious treasure which carries the beauty and charm of the Chinese culture both in form and in content. Therefore, how to adequately reproduce the beauty of the Chinese language and culture is a great task put before the translators. Hybridity in the translation of poems from HLM can help maintain the otherness of the classical Chinese poetry and introduce Chinese culture to the English readers. As for Yang's version, A Dream of Red Mansions adopts the foreignization-certered strategy, trying to retain as many heterogeneous elements of the source text and source culture as possible, which is favorable for reconstructing the identity of the Chinese language and culture in the West. But for Hawkes's version, based on their understanding of the source text and their purposes, the translators have made many adjustments due to some factors, such as the linguistic, cultural and ideological differences. Hawkes's version has low degree of hybridity, although it has attracted many western readers for its readability, it fails to transmit the original culture to the West. Anyway, despite the defects, no one can deny their versions and their contributions to linguistic and cultural communication between the West and China.

In the future studies, hybridity theory should be further investigated in breadth and depth. As for the translation of the poems in Hong Lou Meng, scholars are supposed to pay attention to application of hybridity theory rather than just focus on the discussion of foreignization and domestication. Only in this way can we broaden the research category of translation studies and cultural studies. The famous scholar Lv Jun also points out that the entire post-colonial criticism is under the guidance of deconstructionist theory, which is prone to lead translation studies to lose concern about the ontology of translation and focus on the external factors beyond language $[7]$. Therefore, for the research of poems translation in Hong Lou Meng, only hybridity theory is not sufficient, and "there needs to be other methods and approaches as its supplements" [5].

\section{REFERENCES}

[1] Bhabha, H.K, The Location of Culture, London: Routledge, 1994.

[2] Cao Xueqin, Gao E: Dream of Red Mansions, Beijing: People's Literature Publishing House, 1964.

[3] Cao XQ, "A Dream of Red Mansions". Transl. Yang XY, Yang G, Beijing: Foreign language Press, 2003, p479,38,238,33.

[4] Cao X Q. "The Story of the Stone" Transl Hawkes D, London: Penguin, 1973, p688,55,351,46.

[5] Zhang Zhiqiang: translation version of Pearl Buck's " The Water Margin: Outlaws of the Marsh " in the perspective of postcolonial translation theory [J], Chinese translation, 2010 (2): pp46-50.

[6] Li Heqing, Huang Hao, Bo Zhenjie. Western Translation Studies Methodology: After 1970s [M], Beijing: Peking University Press: 2005

[7] Lv Jun, Hou Xiangqun: Studies of Translation - in a Constructivism Perspective [M], Shanghai: Shanghai Foreign Language Education Press: 2006 